\title{
Skønlitteratur om og fra Sønderjylland $1864-1920$
}

\section{Af H. Lausten-Thomsen}

Medens krigen i 1864 ikke synes at have fremkaldt nævneværdig digtning på tysk, skabte den i Danmark en af vore aller skønneste digtsamlinger: Chr. Richardt's „Et år“.

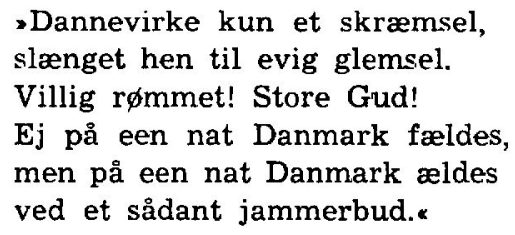

Dybt føler han tidens tyngsei, og han finder udtryk for sine følelser, som ingen anden kunne. Højst når han nok i kirkekantaten under Dybbøl-skansernes belejring "I nød og fare“ med den stærke bøn:

*Vældige Gud, vor og vor fjendes,

o lad det kjendes, med dig vi drog ud!

o lod det dages! O lad det mærkes, mer end de stærkes er Du de svages vældige Gud!*

I august måned er det „sørgetoner", han former, men ved lovfald, medens tågen isner, rosen visner, siv og snerle sammen dor, synger han dog, som vi så tit har sunget med hans ord, om atter at nå forår og ruggrønt land. 
Det er vel også de eneste sange, vi mindes, fra selve krigstiden, selv om Paludan Møller og H. C. Andersen naturligvis også digtede i og om krigen; det blev dog mest kun lejlighedsdigte, døgnfluer og er nu helt glemte. Men så er der jo et norsk og et svensk digt. Der er: Ibsens „En broder i nød:

*Nu flokker sig om Tyras borg, -

kan hænde, sidste gang, -

et folk i nød, et folk i sorg,

med flaget halvt på stang, -

….

Hvert stormsuk, som i Norge går

langs li fra Danmarks hav,

dig sporgende med rædsel slår:

Min bror, hvor blev du af?

Jeg stred en livsens strid for nord:

mit hjemland blev en grav; -

Jeg spejded over bælt og fjord

forgæves dine snekkers spor.

Min bror, hvor blev du af? -

Det var en drøm. Vågn stærk og kæk

fra folkes $\phi$ vn til dâd!

En bror i nød! Hver mand på dæk; -

Her gælder rappe råd!

End kan det stâ i saga slig

dansk, dansk er Tyras vold.

End Danebrogs forrevne flig

kan over Nordens fremtid rig

slå ud $\sin$ røde fold!

Carl Snoilsky, Chr. Winthers svenske ven skrev om:

Storken.

Hvor är du hemma, du storkefar

som öfver ängarne går och spetar?

Du klapprar ängsligt och brådt du har -

hvad är det väl du så ifrigt letar?

Hvar är du hemma? Se så, gif svar!

På mjölnarns stuga vid Dybböls kvarn

jag bodde rymligt, jag och de mina.

Jag tykte mig vara rika karln,

när jag såg soln in i boet skina

på fem välartade storkebarn. 
En morgen blef där et grufligt gny

kring berget krälade pickelhufvor, och mjölnarns stuga brann högt i sky; snart sảg man blott năgra svedda tufvor ach mine små orkat icke fly!

$\mathrm{Nu}$ är jag barnlös och utan hem och går och letar $\mathrm{i}$ våta mossar; jag blir så glad, då jag hitter dem, de rosenkindade danska gossar en gång de hämnas de brända fem!

Fra Sønderjylland ved jeg kun et digt, kanske der findes nogle på tysk; men jeg kender ingen fra selve krigstiden. Hos os er det redaktør Johannes Moldt, der digter, men hans vers kom forst offentlig frem mange år senere. Der er en „Slagton", som han slutter:

Herre, skal det ske, at dagen bringer

sejren ej, men nederlagets kval, at $\min$ bøn did op til Dig sig svinger over tusind brødres lig på val, o, lad hver broders gravskrift være:

- Mod sin moder tro han faldt med ære«! Mens hans øjne lukkes, bring ham bud:

Aldrig Danmarks stjerne slukkes ud.

Kort efter krigen skriver Moldt et længere digt „Før og nu“, hvoraf kun dele er trykt. Det gælder om at holde ud „endog med håb mod håb“.

Sålunde stander Danmark med rent, men brustent skjold, med kors, med tunge tab, med sorg i sinde.

En gang jeg elsked hende, men nu har tusindfold jeg kærere den stakkels blege kvinde.

Så vist et folk kan trykkes, men aldrig slás i kvag, hvis selv ej hånd det rækker, så vist skal gry en dag, da alle sine børn min moder favner.

Det er toner, vi atter og atter møder i udlændighedstidens sonderjydske litteratur. Undertiden synes man endda at genfinde Moldts ordvalg. Der er ikke meget at nævne'af, hvad der 
i krigsảret blev skrevet fra og om kampen i Sønderjylland. Der er et par samlinger af krigsbreve, men at tale om dem ligger uden for mit emne. Derimod kan fra 1869 nævnes „Skizzer fra krigen" af premierlieutenant Michael Giorup, fordringsløse småfortællinger, som efterfulgtes af adskillige avisfeuilletoner og almanakhistorier fra samme hånd.

Samme år kommer Moldts „Hvorfor jeg er bleven tydsk“ selvbekjendelse af Matz Matzen, synsmand, først trykt i hans avis „Dybbølposten“. Satire og drilleri, vid og vittighed har spillet en stor rolle $\mathrm{i}$ hele udlændighedstiden. Smil og latter, lune og godt humør blev våben af værd. Men aldrig har viddet været bidskere eller mere gennemført end i Moldts bog, og i dag er den et kulturelt minde og en kilde til forståelse af tiden, der nok er værd at tage frem efter over 80 år.

Det er en alsisk bonde, hvis nationale livshistcrie forfatteren søger at fortælle $i$ hans eget navn, en historie om den honnette ambition, som fører ham ind iblandt den augustenborgske hertugs tilhængere. Den er parret med en ikke ringe del af uforstand, og til sidst, da hertugen er død og borte, har han ikke let ved at tage prøjseriet:

„Naturen har lige så lidt påtrykt mig tyskhedens stempel, som den har gjort det ved andre tyskere, der er førdte og bårne her til lands. Vi er en kunstfrembringelse, vi har først måttet lære, at blive således som vi nu er ...

Rundt omkring mig taler folket om et gammelt fædreland, til hvilket kærligheden aldrig kan udslukkes, om et modersmål, som det ingen sinde vil slippe. om fortidsminder og sindbilleder, der stedse vil blive hellige og dyrebare, om sæd og skik, som det vil bevare uforkrænket! Slige rørelser har jeg aldrig haft, - hvi skulle jeg da kunne forstå dem? Jeg spørger blot om herredømme og fordel, det er noget, jeg kan gribe og føỉ på, og hvorved jeg kan gotte mig. Min bestræbelse er derfor altid gået ud på at holde mig til den side, hvorfra disse herligheder kunne annammes." 
Der er adskilligt i Moldts bog, der kan ramme hårdt endnu. Den er sønderjydsk satires hovedværk. Det er kun småt, hvad der er fulgt i dens spor, og der er næppe grund til at nævne andet end møller Jørgen Fausbøls lille "Germanomani" med de kostelige histcrier om hjemmetyskernes færd, de 7 tyskere fra Branderup og den Tøndring købmands rejse til Uge. Hvad Skovrøy skrev under mærkerne „Scapin“ eller „Henrik“ og Anders Lebeck under "Oldfux“, nåede ikke ud over dagbladenes spalter, men gjorde endda nytte på deres vis.

Allerede i 1864 havde H. F. Fejlberg i sin ypperlige bog „Fra heden“ aftrykt en sang af en nulevende bondekarl Karsten Thomsen:

„ hør min Pigh, å si do mæ, vil do int væhr min Kjærrest? *

Karsten Thomsen er vor første virkelige digter på sønderjydsk stedmål, der er ynde og dybde i hans tanker og klang i hans Frøslevmål. Det er ikke mange sange, Thomsen har skrevet, men Barnekows og Morten Eskesens melodier og sang har båret dem ind $\mathrm{i}$ hjemmene, og $\mathrm{i}$ min barndom og ungdom var det en selvfølge, at vi kunne dem udenad og sang dem ved vore sammenkomster:

"De var en daw i høstens ti'

da Pers slow row for fuld!

Der gik en pigh å værret hø. -

elier

स gær så javn og plower",

"Skal Sønderjylland skilles

for åltids frå sin mor? «

fra 1868 .

Det er aldeles samme toner som præsten $J$. $J$. Lohmanns „Den ti te do drow fra mæ, da bløv a så åljen, som a âller forren ha væn". (Han er fra Haderslev).

En anden, muntrere tone lyder fra en anden præst Kristen Karstensen, født i Kær, Ulkebøl sogn. Han skrev sin Alsing 
- Vihs "La vos syng vos en vihs o vort ældgamle dansk", den der ender med

•å masjer, nær der tælles med ein, zwei, drei, det er trågt for e bin å find å den vej*.

Karstensen synger om Sundeved „Der er et land, af herren rigt begavet, og om Als "Af Østerhavets vove en $\varnothing$ sig hæver skønt“. Her må vist også nævnes P. Hansens: „I Arilds tid, da end begravet", sangen til Skamlingsbanke, hvis sidste strofer mange af os ikke kan møde, uden at de for os bærer præg af H. P. Hanssens mund:

En grænsevagt, som ikke segner og giver fejg sin post til pris.

En kæmpeslægt, som ætten regner fra Ebbesen på Nørreris

I 1869 udkom der i København et bind „Sønderjydske toner“ skønt". Her må vist også nævnes P. Hansens: „I Arilds tid, da bårne af dyb fædrelands kærlighed, typisk for det meste af, hvad der under fremmedherredømmet skreves på vers i Nordslesvig:

- Hver gang bedeklokken udsender hellig klang, og sangen toner hjerteligt og sødt i Dannevang, da flyver over land og det bølgende blå det $\emptyset$ nske: Gud give, det skilte samles må.»

For at få rim kaldes havet „det bølgende blå“, men meningen er god nok. Der er tro til fremtiden, tillid til, at genforeningen nok skal komme, $i$ alle tidens danske vers.

Theodor Wulff, søn af den rige kniplingshandler Jens Wulff i Brede, lod i 1857 i sit hjem opføre en operette „Konduktøren“, som han selv havde skrevet både tekst og musik til. I 1873 fulgte hans store opera "Aksel og Ingeborg" og 1884 en operette i 3 akter "Deserteuren“, som i 1923 igen blev opført i Tønder. Desuden foreligger der fra Wulffs hånd nogle ballader med emner fra nordslesvigske sagn, udkomne i Flensborg 1885 
og 1886. „Rosen fra Apenholdt skov“, „Ridder Flemming eller Røverborgen på Rømø" og flere, de fleste først trykte i Nordslesvigsk Søndagsblad. Det er ejendommeligt at tænke sig, at man har kunnet udføre dette med lutter stedlige kræfter i en afsides liggende landsby under prøjservældet.

Det er grumme lidt, der ellers fra disse år kan henregnes til dansk skønlitteratur, nogle småfortællinger af Bendix Hansen, samlede og udgivne med en levnedstegning ved Zacharias Nielsen, godt håndværksarbejde i smag med den såkaldte skolelærerlitteratur, skønt det ikke når på højde med dennes bedste frembringelser, og så Hother Tolderlunds noveller, som fremkom i tidens ugeblade, især Illustreret Tidende, under mærket $D r, H$. Det er stille, men i deres præg aldeles troværdige smånoveller, fortalte med ikke ringe formel dygtighed. „Flensborg Avis" har for nogle år siden genoptaget nogle af dem uden at nævne forfatterens navn. $H$. A. Malling, amtsforvalter i Hütten amt, udgav i 1876 et bind "Fortællinger og skitser" uden nogen som helst litterær værdi.

Ellers er det $i$ dette tidsrum mest mindebøger fra tiden før og imellem krigene, der taler om Sønderjylland, og det er kun fá af dem, der kan nævnes som bare i nogen grad hørende til skønlitteraturen og iblandt dem ikke Mallings „Efterladte erindringer", som udkom 18 år senere. Dog må fremhæves provst Høyer Møllers bøger, og af disse især „Tre af mine venner, afbetaling på min gjæld af en gammel feltpræst“, 1878.

Der har været en tilbøjelighed til at tale overlegent om sydslesvigsk tysk kultur, til dels er det vel, fordi vi kun kender så lidt til den. Vi må dog ikke glemme, at den i prøjsertiden har fostret mænd som historikeren Mommsen og filosofen Friedrich Paulsen, hvis navne godt kan tåle at sidestilles med A. D. Jørgensen eller Harald Høffding, og på litteraturens område har Sønderjyllands største været Theodor Storm fra Husum, fra byen ved det grå hav, „die Stadt am grauen Meer". Han er mere end en dygtig versificator og en habil fortæller. Der er 
en stille idyl i mange af hans noveller, allerede $i$ den første "Immensee"; men der er mere: et digtersinds rigdom, en ren skønhedsglæde og en dyb forståelse for dem, der lider ilde. Romanen „En fest på Haderslevhus“ fortæller om Lembækkere på Tørning i 1300 - tallet. Storms digtning er både i vers og prosa, især prosa, det bedste, der er skrevet i skønlitterær form i Sønderjylland i sidste århundrede. Lad mig kun nævne et par noveller fra bindet „Am grauen Meer": „Psyche“, et indtagende billede af en ung pige, og "Viola Tricolor", et ungt ægteskabs historie, begge fyldte med virkelig og ægte følelse, men det kan ikke nægtes, at for en dansk læser kan udtrykkene blive for højt stemte og undertiden komme til at virke anderledes, end digteren må have tænkt.

Storm var advokat i Husum og langt fra Danmarks ven. Det samme kan også siges om Hermann Heiberg i Slesvig, men der er ikke grund til at dvæle ved hans romaner, der nu er så godt som glemte. Derimod frembragte Erich Schlajkjer fra Aabenraa blivende værdier i "Der Schönheitswanderer" i "Mein Freund Niels" og i skuespillet „Des Pastors Rieke“, som Georg Brandes skrev en meget rosende artikel om. Schlajkjer var hjemmetysker med en ulykkelig kærlighed til Danmark og alt dansk, en mand med tvesind også på andre områder og med en trang skæbne, men en virkelig digter.

På grænsen mellem tysk og dansk sprog står Tøndringen Lorenz Holm Andresens lystspil i det ejendommelige, nu uddøde stedmål, hvis grundlæggende danske sprog var overbroderet med tyske vendinger og enkeltudtryk. De er endnu efter genforeningen spillet $\mathrm{i}$ Tønder under stort tilløb.

I Tønder, udgående fra byens seminar, levede også i adskillige år Wilhelm Lobsien, der har skrevet „Das Rosendach. Die Geschichte einer nordschleswigschen Jugend“, som fortæller roligt og pænt om Tønder og Vestslesvig, medens „Halligpræsten“ foregår noget sydligere, begge virkeligt dygtige værker, der hæver sig adskilligt over gennemsnittet. 
Endelig henlægger den nuværende slesvigholstenske minister Eduard Edert handlingen i "Der Schuster von Tondern" til denne by. Den giver billeder fra lavsvæsenet, kanske ikke lige pålidelige i enkeltheder, men er rigtig pænt fortalt.

Lobsien er søn af en tolder i Foldingbro; men Johannes. Dose er født i Ødis. Han har skrevet mange romaner, for det meste med historisk stof "Der Kirchherr von Westerwohld", „Frau Treue“, „Düppel. Ein Kriegsroman“, „Der Kampf um die Nordmark“ og den store „Des Kreuzes Kampf um Dannevirke“. De har opnået mange oplag i Tyskland, men er ret ufordøjelige for danske læsere. Det er således ikke helt let at tage, når han i den sidstnævnte bog fortæller, at indskriften på Jellingestenen bør udvides med, at Harald blev kejserens ven. Doses danskfjendtlighed svandt dog stærkt efter genforeningen, da han havde brændselsforretning på Ulvslyst og tilbød sig som medarbejder ved "Slesvigsk Søndagsblad“.

Charlotte Niese fra Femern skrev småfortællinger og „Aus dänischer Zeit", og Feodora, prinsesse af Slesvig-Holstein, udgav digtsamlinger og en prosabog „Durch den Nebel“ fra Slesvigs østkyst. Hendes navneskjul var F. Hugin.

Nicolaus Fries fra Flensborg skrev religiøst prægede småfortællinger (Das Haus auf Sand gebaut) og Johann v. Wildenradt fra samme by skrev romaner og digte med historisk baggrund. Begge levede i Tyskland.

Når jeg til sidst i denne sammenhæng nævner, at August Iversen fra Tønder udgav et bind plattyske eventyr, er jeg aldeles klar over, at der kunne peges på adskilligt mere, dels fordi det er undgået min opmærksomhed, dels fordi jeg ikke har fundet det værd at nævne. Dog bør der retteligt endnu mindes om, at selve pastor Jacobsen i Skærbæk 1907 skrev en roman, „Zwischen zwei Meeren", hvori han fortæller om sin ungdom - 1. Ebbe und Flut, 2. Sehnen und Suchen, - og at redaktør Jacob Bödewadt i Tender under samme ordtag samlede en snes sydslesvigske fortællinger og skitser. 
I 1877 udsendte Holger Drachmann „Derovre fra grænsen“, lyriske rejseskitser fra Als og Sundeved, en bog, der fandt flere læsere end nogen tidligere bog med samme emne, og en bog med blivende værd. Der er først det henrivende friske billede af skorstensfejersvenden på Dybbøl banke med den flotte og flot gengivne fortælling om kampene i 1864, og så er der sangen fra Bøffelkobbel: „De vog dem, vi grov dem ....." Der er mere af Holger Drachmann end af de gamle Finks i sangen, og tonen synes i dag ikke mere helt ægte.

... Lad tøjterne ved Elben være tyskerne parat, enker er de sønderjydske piger.

De sidste ord blev senere lagt Marie Skau Petersen i munden; men sandheden er, at det er Drachmanns og ikke Marie Skaus ord, selv om de rummer en kerne af sandhed. Svagere end "Derovre fra grænsen" er „Danmark leve“, som kom 8 år senere. Holger Drachmann var ikke den mand, hvis tankeflugt tillod ham i lange tider at være optaget af samme emne; men endda har han $\mathrm{i}$ disse to bøger, $\mathrm{i}$ "Danmark leve" især ved skildringen af $\mathrm{P}$. Skau og hans to dotre - skabt noget af det værdifuldeste $\mathrm{i}$ den bogverden, her tales om. I den sidstnævnte ligger krigens skygge ikke så tungt over fremstillingen som i „Derovre fra grænsen“: Tiden mildner og dæmper både sorg og savn. Karl Gjellerup lader 1882 en del af sin roman „Germanernes lærling“ foregå i Vonsbæk. Der er et par friske naturskildringer; men alt hvad han ellers fortæller fra sognet, er utroværdigt og forvrænget.

En af soldaterne fra 64, Erik Skram, foretog i 1886 en rejse $i$ det fraskilte land, og han fortæller $i$ en lille bog „Hinsides grænsen " med megen finhed om sine krigsoplevelser. Det er denne fortælling, han slutter med billedet:

"I Sundeved har jeg en aften i en have siddet sammen med tre slægtled af en bondefamilie, begge bedsteforældre, gifte og 
ugifte børn og børnebørn. Bedstefaderen havde sin dattersøn stảende foran sig mellem benene, drengen brugte dem som armlæn, datteren vuggede sagte sin lille pige på skødet. Den gamle foreslog, at de skulle synge, og med kraftige stemmer tog de fat. Den ene fædrelandssang blev sunget efter den anden. Aftenen var stille, det blev svalt, solen var forlængst gået ned, stemmerne lød hårdt $\mathrm{i}$ den klare luft. Drengen stod og lyttede til.

Det var Sonderjyllands historie i de kommende lange år, jeg så: Barnebarnet, der nemmer, hvad der bliver sunget og talt i dets fødestavns luft. -

I tonen nærmer P. Fr. Rist's roman „En rekrut fra 1864“ og ..Efter Dybbøl“, især den første sig stærkt til Skrams bog ved tegningen af den friske, lyse Felix i kampene. Der er ikke $\mathrm{i}$ nogen af disse bøger - ud over enkelte tilløb i „Derovre fra grænsen" og i „En rekrut" nogen realistisk skildring af krigens rædsler. Snarere ligger der endnu mindelser fra $H$. P. Holst's sang i 1850 "Slumrer sødt i Slesvigs jord" med det dybt usandfærdige „Skøn er døden, som I fik". Det er først Herman Bang, som finder udtryk for krigens opløsning af alle forhold, nedbrydning af moral og gru i menneskesjæle, og det er i bogen "Tine“ af 1889. Lad være, at der både er hysteri og villet usandfærdighed i, hvad der fortælles, så er både Dannevirkenatten og brandene over Als aldeles ægte $\mathrm{i}$ den tone, der ligger over ordene.

Som et uhyre tæppe, gennemboret af batteriernes glimt lå jen væltende røg ud over landet. Og foran den stod, fra landets bund, mægtige søjler af sort os, omvundne med flammer, som vældige støtter op imod himlen - huse og byer, der brændte til grunden.

Madam Bølling talte ikke. Forfærdet begyndte hun at ryste og førte, som ville hun bede, stum og angstfuld de foldede hænder op og ned. 
Bølling havde set hende, men han rørte sig ikke.

Han tog kun sin stck og førte den i sin rystende hånd, pegende rundt fra søjle til søjle og talte med sit svære mæle:

- Det er Ransgårde.

- Det er Staugárde.

- Det er Dybbøl.

Madam Bølling kunne ikke tale. Heller ikke græd hun. Hun blev kun ved at bevæge de foldede hænder hjælpeløst op og ned.

- Det er Dybbøl, sagde Bølling igen.

- Du må ikke stå her, sagde madam Bølling så og rev ham med sig, løbende med den syge ned over pløjelandet, bærende ham halvt.

- Du må ikke stå der.

Det var som kanonernes drøn sagtnede nu. Bølling gik mimrende, med det rokkende hoved. Og støttende manden, selv lammet, fandt madammen ingen ord i sin forfærdede hjerne og sagde kun som Tine før - to gange:

- Ja, alting er ude af gænge.

Der kan også her mindes om Niels Lyhnes død i J. P. Jacobsens roman. Han ligger på lazaret på Als. Hjerrild, der var læge ved lazarettet, sørgede for, at han blev lagt ind i en mindre sal, hvor der kun var fire senge. Den ene af dem, der var derinde, var skudt i rygraden og lå ganske stille, den anden havde sit sår i brystet, han havde ligget der et par dage og fantaserede hele timer i træk med hastigt udtalte, afsnubbede ord; den sidste endelig, som lå nærmest Niels, var en stor, stærk bondekarl med tykke, runde kinder; han var bleven ramt i hjernen af en granatstump, og uafladeligt, time ud og time ind, løftede han, omtrent hvert halve minut på en gang højre arm og højre ben i vejret og lod dem så straks falde tilbage igen, ledsagende bevægelsen med et tydeligt, men dumpt og tonløst: Haah - hoh, altid i samme takt, altid nøjagtig ens, haah, nảr han løftede lemmerne, hoh, når de faldt ned .... 
..... Hjerrild rejste sig. „Farvel, Lyhne," sagde han, det er dog en smuk død, at dø for vort stakkels land."

..Ja,“ sagde Niels, „men det var dog ikke på den måde, vi drømte om at komme til at gøre fyldest den gang for længe, længe siden." -

Imod morgenstunden begyndte han at fantasere, betændelsen var i fuld gang.

Og sådan blev det ved $i$ to døgn endnu.

Sidste gang Hjerrild så til Niels Lyhne, lå han og fablede om sin rustning og om, at han ville dø stående.

Og endelig døde han da døden, den vanskelige død."

Et par år ældre end Tine er Rudolf Schmidts Jochen Hinrichs, hvis handling er henlagt til 1850. Oll Jochen sender bud til oprørerne om, hvor den danske feltvagt ligger. Hans egen søn fører dem ved et planlagt overfald, og Jung-Jochens lig bæres ind $\mathrm{i}$ faderens gård. Hans had til danskerne svinder først, da han oplever det prøjsiske regimente, og til sidst når han til at sige: „De Dänen harrn Recht!“.

I firserne udkom også $A$. B. Thorsons to bøger „Skæbner og viljer", to fortællinger fra Slesvig og "Gennem ilden“. I den sidste fortælles $\mathrm{cm}$ en ung tysk præst, som vinder en dansk brud og søger over til hendes nationalitet. Den er ret naiv; men spørgsmålet optræder jo adskillige gange $\mathbf{i}$ vor litteratur, sidst hos Nicolaj Svendsen.

Den norskfødte Laura Kieler er i en af sine mange sønderjydske romaner inde på et lignende spørgsmål, muligheden af samliv mellem en tysk mand og en dansk kvinde; men som i „Dit folk skal være mit folk“ er også hendes andre bøger hæmmede af, at hun kender Sønderjylland, dets skæbner og hændelser på afstand. God vilje drager tungt læs, siger ordsproget, men den magt, der ligger i viden og kendskab, kan ikke lades uænset. Ferdinand Zeemanns „Et dansk hjem i Sonderjylland" 1894 fortæller om Thomas Schmidt fra Egernsund, der ikke ville sværge til prøjserne. 
Carl E. Simonsens „Danmarks grænsefolk“ og andre meget læste romaner fra Sønderjylland fortæller mere $\mathrm{cm}$ hans kærlighed til og optagethed af sønderjydske emner end om hans fortællende evner og den noget senere (1910) udgivne „Søren Mathiesen \& Co. eller kejserens udsending“ af Ferdinand Petersen, vistnok et navneskjul, viser en næsten utrolig mangel på viden om de sønderjydske forhold, som bogen søger at skildre, endnu storre mangel end Simonsens.

Martha Ottosen har i „Ruth's far" og i "Danmarks grænsevagt mod syd" givet gode billeder af sin far Gustav Johannsen cg den kreds af Flensborgere, der samlede sig om ham. Hendes skuespil „Fædrenes jord“ var både dygtigt og nyttigt, i dag er det et smukt stykke Nordslesvigs historie. Hendes mand Johan Ottosen skænkede os i den gamle folkesangs rytme sangen "Det haver så nyeligen regnet", som vi vel alle sammen kan udenad. Det var vist mere end et tilfælde, at det var samme verseform, bankbestyrer Svend Kjeldskov valgte til sin anonyme sang, "Sønderjyden har underlige vaner" $i$ vittighedsbladet „Puk“ i 1897. Værdifuldest af de sange, vi ellers fik fra kongeriget i udlændighedstiden, var vel ellers ved siden af Valdemar Rørdams digte „Der er vel dag til suk og gråd“ af Niels Møller. Lad mig ellers af disse kun nævne „Hist på pælen sidder Mikkel" af Th. Kühnell (1867) og Kallenbach Peders€ns adskillige år yngre „Når tysken sparger dernede ved Spree".

Der fremkommer $\mathrm{i}$ disse år overordentlig lidt i bunden form og af blivende værd $i$ de sonderjydske landsdele. Kun to sange finder optage'se i „Den blå sangbog“, Laurids Krogs „Elsk Dit land!“:

Elsk dit Sprog!

Nyn det for din lille pog.

Kvinde, lær ham det at stave!

Det er livets bedste gave, dronningrosen fra den have, hvori fædres hjerter slog. 
Det blev ellers mest til smårimerier, hvad Krog skrev, tit dog med satirisk bid. Rasmus Clausen fra Smedager kunne også forme gode vers; egentlig digtning er det heller ikke; men vi var taknemmelige for dem; han priser sin hjemegn, og han kunne danne korte og knappe vers:
Aldrig tab dit mod, håb kun ufortrøden!
hjælpen nærmest er, når størst synes nøden.
Derfor ho'det op, ingen bør forsage!
Efter mørken nat kommer lyse dage.

11 af Rasmus Clausens digte findes i Sprogforeningens almanak. Hvad der er trykt af den slags findes nu i dagblade og almanakker. Der er årgange af „Dannevirke“ med en mængde rimede indlæg af $P$. Eliassen, Hans Petersen og fru Karen Andresen Mathiesen, som også skrev et „tidsbillede fra Sønderjylland": „Ved Kongeåen,“ som på ingen måde hæver sig op over bravt håndværk. Det samme må siges om fabrikant M. Andresens "Tvillingbrødrene“, som under navneskjul kom i samme avis's fraklipningsfeuilleton. Ikke ilde er derimod, hvad fru Mathiesens mand, redaktør M. C. Mathiesen under navnet Cornelius Vraaby skrev i Andresens børneblad. I „Højskolebladet" vil man kunne finde adskillige velformede vers af Chr. Højer, og i „Flensborg Avis“ af P. Kjcer fra Arrild, der tit skrev i stedmål.
Den, hvis økonomiske kår er blide, en stor opgave venter på, fordi
en dansk, som bor på livets skyggeside,
for ham må sættes flere vindver i.
I sluttet trop vi kampen op må tage, vi løfter mest, når vi går frem i flok.
Al standsforskel den lader vi tilbage, ved sammenhold da klarer vi os nok. -

An Aadams, gift med Jørgen Hansen, kaldet Blank, i Tinglev sogn, sidst Terkelsbøl, formede en mængde smådigte, som først er fremkommet efter genforeningen, hvorimod vandre- 
lærerinde Henriette Gubi's „Efterladte digte“ i 1901 blev udgivet af redaktør Hans Petersen. Også i disse digte mærker man den redelige vilje, det ærlige sindelag, men der er næppe noget eget, nyt billede i dem, næppe et fejlfrit vers.

Af digtningen på folkemålet er det meste og bedste kommet i "Sprogforeningens Almanak“; foruden Nic. Andersens i 1926 et af præsten i Rinkenæs $N$. J. Jensen, hvis hovedværk ellers er det store digt om Simon Peder, 20 sider gode vers $i$ folkesproget, som det tales nord om Flensborg fjord.

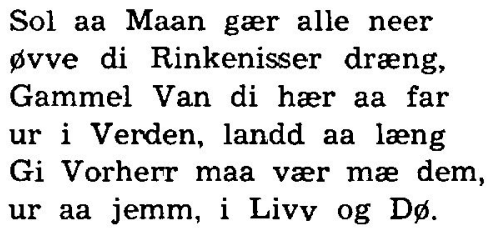

Der har lydt mange gode ord om denne gode, danske mand og tyske statspræst efter hans død, skønnest Valdemar Rørdams:

Se, det var smukt, - idet vi dog skal dø at dø som han. Det gør mig glad at vide: De fandt ham som et korn, et blomsterfr $\varnothing$, midt på den friske jord ved forårstide.

Lad mig minde om, at det var samme år, 1906, at Rørdam sang om redaktør Jessen:

- Der er styrtet en eg i den stormslagne lund, der er vej, hvor den vældige stod.*

Allerede tidligere havde Nicolaj Andersen vist, hvor smukt og alvorligt man kan tale og synge $i$ folkemål i digtet Gammel Kjærlehe „Hun sirre den gammel å spinde“. - Jeg skal ikkt komme ind på hans dejlige rimede anekdoter, hvem husker ikke: „E natue gær øwer e optugtels,“ „Hjælp mæ, Jes, a døe, a døe" eller „E dreng o e præst.“ Flensborg Avis havde bragt adskillige bidrag af ham i prosa "Te awtensæe" og 
andre,og i den udgave af hans digte, som Sprogforeningen har udgivet, findes der 5 historier i stedmål. Hans vid har dog udfoldet sig lige så klart i de fortællinger, almanakken hvert år bragte. Det tør vist også være på tide, at vi får en samlet udgave af dem. De har ikke bare historisk, men lige så fuldt litterær værdi.

Foruden dennes almanak var der især to andre, som søgte at tilfredsstille Nordslesvigs trang til dansk læsning.

Der $\mathrm{er}$ først Drohses almanak fra Tonder, hvis fornemste medarbejder var lærer Borst fra Mjolden. I Fr. Fischers stil lavede han små historier om nordslesvigske sagn eller små historiske hændelser. De er samlede i 2 bind "Schleswigsche folkesagn“, udkomne på Schützes forlag i Haderslev. De var i mange år meget yndet læsning ligesom „Tule Vognsen, Originalfortælling fra Nordschleswig af Arnold“ på samme forlag. På den dristigste måde blander Lorenz Borst her sagn og historie fra Valdemar Atterdags og Chr. IV's tid; men der er ikke så lidt håndelag $i$ fortællingen. Her stod også nogle småskitser på stedmål af lærer Pedersen Hjeds.

Drøhses gamle almanakker er nu sjældne skatte, og det samme gælder Christelig Folkekalender for Nordslesvig, trykt og forlagt i Breklum. Den bragte mest oversættelser fra tysk, småfortællinger og religiøse overvejelser, men op deri lyste Nemos digte og fortællinger fra Sønderjylland, og vi vidste jo godt, at Nemo var præsten Nicolai C. Nielsen fra Højrup, senere fra Sommersted, den afholdte og højtagtede "sidste slesviger", som han yndede at kalde sig. Hans bøger, hvoraf der efterhånden kom ikke få:

Kristelige fortællinger og digte for folket.

Fra Schæfergården.

En rejse omkring i mit hus.

Slesvigske fortællinger.

Endnu en gang på rejse,

bæres af hans inderlige, dybe tro, af hans bundethed af og kærlighed til hjemstavnen og hans vidtspændende kulturelle 
interesser. I grunden var han vel mere dansk end tysk, men forst og fremmest slesviger og evrigheden underdanig. Han skrev ved en vens død:

Kort var dit liv, svær var din sot, enke og børn stå forladt, Et dog du fik, Et dog du vandt, Et som jeg priser til sidst som en skat, En grav i vort slesvigske land.

R.ølgen den skvulper, det hvisker i rør, hvor kirken på landtangen stàr. Bøgen den knoppes, kastanien bli'r rød, det evige hav som et orgel-

om din grav i vort slesvigske land! værk går

Hvor de lysgrønne linde om gravstedet står på vor Kirkegårds fredede plet,

Der lad mig og finde, når striden er endt - ja herre min freiser, Min grav i vort slesvigske land. du give mig det,

Siden 1894 er det dog stadig Sprogforeningens Almanak, der bringer det bedste, og ved siden af, hvad Nic. Andersen skriver, er det Skovrøys fortællinger, man altid først greb efter. Det er ikke færre end 28 af dem. De er samlede i bøger: "To fortællinger“, „Mandsmod“, „Hundevagten“. Dybest når han nok i "De gamles by" fra 1898; men i enhver fortælling møder man hans milde livssyn, hans muntre indstilling og hans lyse tro til tilværelsen. Han er modersmålets elsker og ridder. Smukkest fortæller han derom i digtet „En julegæst“, men nærmest kommer man vel nok Skovrøy $i$ hans to sammenhængende store bøger "Den gamle mølle" og „Lys på møllen", der rummer en stor del af Tønders og vesteregnens overlevering, præget af forfatterens milde forståelse. Overordentlig smukke er også nogle af de småstykker, han „i ny og næ“ skrev i sit blad "Vestslesvigs Tidende“, og hans „Hundevagten, tredive år $\mathbf{i}$ Tønder", er et sandt og stærkt kulturbillede.

Nicolai Svendsen kaldte sig Broder Boysen, da han skrev sin første bog "Mens stormen raser". Medens Skovrøy bygger på sit lune og sin naturlige evne til at skrive, er det intelligens og viden, som ligger bag Svendsens bøger. Den første er sikkert den bedste med den indledende ypperlige stormflods- 
skildring og den dybt forstående opfattelse af hans hjemstavns folkepræg. Næste bog „Hjemstavn“ søger at nå længere ind imod en mands åndelige vækst. Emnet ligger nært op ad A. B. Thorsons "Gennem Ilden“. Men her er præsten, som giver afkald på sit statsembede og vinder sin danske brud, Nordslesviger og derfor så langt lettere at tro på. Man tror $\mathrm{i}$ det hele taget på, hvad Svendsen fortæller. Han har brugt sine øjne og han kan fortælle, både mundtligt og skriftligt. Det er bøger, man trygt kan henvise den ungdom til, der onsker at kende Nordslesvigernes danske sind og færd, medens prøjserne rådede $\mathrm{i}$ landet.

Valdemar Rørdam har skrevet et forord til anden udgave af "Mens stormen raser". Der var en tid, da man ville have undgået at nævne hans navn eller $\mathrm{i}$ det mindste kviet sig ved det; men vi må vel efterhånden forstå, at hans sind allerede var formørket, inden han slog ind på Hitlertidens onde veje. Da havde han allerede længe fortalt om hallucinationer som om virkelige oplevelser på en Tysklandsrejse. Et par gange har jeg aJlerede nævnt hans navn, og hvorledes skulle jeg kunne tale om dansk litteratur i Sønderjylland uden at nævne de sange, der tit gav vore nationale møder tonen: I sommersol og blæst; Sorgløst kan vi ej synge dit navn; Danmark i tusind år. Hans „Den gamle Kaptajn" blev ikke, hvad han håbede, en dansk Fänrik Stål; men hans digte, tildels samlede i „De dernede“, var med til at give os styrke og kalde på landsmænds medhu.

Vore egne sønderjydske digtere sang ikke så højt. Præsterne Zerlang og Carsten Petersen havde endnu hensyn at tage. Deres tunge var bundet. Det var Hansigne Lorenzens eller Sven Tanges ikke mere; men hendes sang lyder først klarest og renest $\mathbf{i}$ krigstiden. Hendes mand var endnu lærer i tysk tjeneste, da hendes første bøger udkom. Det var et vovestykke; men det var gode og nyttige bøger, hun skrev, og der gik flere år, inden tyskerne opdagede, at det var en lærers hustru, som skrev med så ægte følelser og sikker viden om kampen mellem dansk og tysk, og da var Hans Lorenzen forlængst ikke mere 
lærer. I „Der kæmper et folk“ har Sven Tange brugt sin egen fader som model. I den næste "Der stander en strid" er emnet det samme som i Thorsons "Gennem Ilden" og Svendsens „Hjemstavn“, præsten, som bryder statsstillingens bånd for at gå med i folkets kamp og arbejde. Så fulgte „Så lægges den sæd“. Der er fine naturbilleder i alle tre, der er et nænsomt kvindesind, det er bøger, man kan vende tilbage til med glæde, men bedst synes mig den næste lille fortælling "Thøge“. Denne stærke vestjydske bonde og handelsmand synes jeg ligefrem at have kendt.

Vel vidste vi, at Sven Tange kunne skrive vers, men hendes første større digt "Arveguld“ udkom først i 1919, og hendes lyriske hovedværk „Tider og steder“ 1927.

Præsten Johan Zerlang i Gram havde i mange år ladet sine oversættelser fra islandsk og sine smådigte se lyset $i$ „Flensborg Avis“. De havde vist, hvor påvirket han var fra Island og fra vore egne folkeviser. Lidt klinger var hans tone tit, men fin hans form og udsøgt hans ordvalg, og indholdet svarede helt til formen. Samlet udkom "Tanker og toner" først efter hans død.

Den lange lyse dag er leden med fuglesang og forårsblæst, og solens gyldne bold er gleden bag bakkekammen i nordvest.

Og aftenklokkens toner ringer farvel til dagen, som skal d $\phi$, og natten breder sine vinger og skygger over land og $\$ \varnothing$.

skært og stille, men således så pastor Zerlang sit land:

Alt kortes de lyse dage, alt længes den mørke nat, og løvet falder så fage, og græsset falmer så brat, og blomsternes blide фjne er brustne $i$ d $\varnothing$ dens blund, og alle fugle er fløjne, som sang i den grønne lund. 
Kanske skulle jeg også have nævnt Anne $M$. Calløs „Til mine drenge", Chr. Gannerups digte i Dannevirke, ikke mere end nævnt; men pastor Carsten Petersens i Brarup, i Flensborg og Maugstrup, udgav også først sine digte „Mit land“ i 1919. Lad mig slutte med det sidste vers i hans bog:

Bred dine arme og tag mig i favn.

Intet, slet intet jeg evner og ejer.

Vær du min tanke, mens Gud er min sejr.

Skriv i min livsbog dit dejlige navn, ældgamle Danmark, -

Tyndt og lidt, men altid rent og redeligt, kan det synes, hvad vi levede på af dansk litteratur i Nordslesvig. Meget af det vil med rette glemmes, men huskes må det, at det var med til at bære os gennem de tunge tider, at igennem disse fortællinger og digte viste vort folk sit sind og så vi tit og tydeligt Danmarks åsyn.

Mangfoldigt og mange gange overfladisk, men alligevel en side af sønderjydsk væsen, vi nødigt havde måttet undvære. Derfor har det også været en glæde at sysle med og samle stoffet, og jeg har gerne villet lægge det frem. 
